\title{
STRUKTUR POPULASI IKAN TERI HITAM Stolephorus commersonii DI TELUK PALABUHANRATU
}

\section{POPULATION STRUCTURE OF COMMERSON ANCHOVY Stolephorus commersonii IN PALABUHANRATU BAY}

\author{
Nufaiza Fitri Chandra Utami ${ }^{*}$, Mennofatria Boer ${ }^{2}$, dan Achmad Fachrudin ${ }^{2}$ \\ ${ }^{1}$ Program Studi Pengelolaan Sumberdaya Perairan, Sekolah Pascasarjana, IPB \\ ${ }^{2}$ Departemen Manajemen Sumberdaya Perairan, FPIK-IPB \\ *E-mail: Nufaiza.fitri@gmail.com
}

\begin{abstract}
Commerson anchovy Stolephorus commersonii is one of the pelagic fish that has an important role and has a big potential for fishery production in Palabuhanratu bay, proved by the number of fluctuating catches with an increasing tend. Increasing fishing activity and the fears could harm the resource sustainability, so the determination and implementation of fish sustainable policy should be undertaken. The research was conducted to discover the reproduction and dynamics of commerson anchovy populations. Fish sample were collected in May to September 2017. Analysis data consist of sex ratio, phase of gonad maturity level, distribution frequency of length and the relation of length and weight. The result shows that 1838 specimen for fish example are not balance with a ratio male and female of 1: 1.7 or $36.96 \%$ : $63.04 \%$. Dominant fish were caught on grade $48-56 \mathrm{~mm}$, while the gonad maturity level on 91 to $94 \mathrm{~mm}$ in August. The growth pattern of anchovy has a relation with length and weight that tends allometric negative dominated by young fish and should not be catch, therefore closing area or season fishing, settings mesh size, and fishing gear is needed to prevent damage to the aquatic environment.
\end{abstract}

Keywords: allometric negative, commerson anchovy, dynamics population, Palabuhanratu bay

\begin{abstract}
ABSTRAK
Ikan teri hitam Stolephorus commersonii merupakan salah satu ikan pelagis yang memiliki peranan penting dan berpotesi cukup besar bagi produksi perikanan di kawasan Teluk Palabuhanratu dibuktikan dengan jumlah hasil tangkapan berfluktuasi dengan kecenderungan meningkat. Aktivitas penangkapan ikan yang terus meningkat dan dikhawatirkan dapat membahayakan kelestarian sumberdaya, sehingga penetapan dan penerapan kebijakan pengelolaan sumberdaya ikan berkelanjutan mutlak harus dilakukan. Penelitian dilakukan untuk menganalisis reproduksi dan dinamika populasi ikan teri hitam. Pengambilan contoh dilakukan bulan Mei sampai September 2017. Analisis data terdiri dari nisbah kelamin, fase tingkat kematangan gonad, sebaran frekuensi panjang dan hubungan panjang dan bobot. Hasil penelitian menunjukkan bahwa ikan contoh yang diambil berjumlah 1838 ekor tidak seimbang dengan perbandingan jantan dan betina 1:1,7 atau 36,96\%: 63,04\%. Ikan dominan tertangkap pada selang kelas $48-56 \mathrm{~mm}$ sedangkan puncak tingkat kematangan gonad pada selang kelas 91-104 mm di bulan Agustus. Pola pertumbuhan ikan teri memiliki hubungan panjang bobot yang bersifat alometrik negatif didominasi oleh ikan yang masih muda dan seharusnya tidak boleh ditangkap, sehingga perlunya penutupan daerah atau musim penangkapan dan pengaturan mata jaring dan alat tangkap untuk mencegah kerusakan lingkungan perairan.
\end{abstract}

Kata kunci : alometrik negatif, dinamika populasi, Teluk Palabuhanratu, teri hitam

\section{PENDAHULUAN}

Palabuhanratu memiliki Pelabuhan Perikanan Nusantara (PPN) yang menjadi basis perikanan tangkap terbesar di Provinsi Jawa Barat dimana pemanfaatan sumberdayanya menurut Dinas Kelautan dan Perikanan Kabupaten Sukabumi mencapai 
10.357 ton pada tahun 2014 kemudian menurun sampai tahun 2016 yang mencapai 3.839 ton. Palabuhanratu merupakan tempat pendaratan berbagai jenis ikan, terutama ikan pelagis. Ikan teri hitam (Stolephorus commersonii) merupakan salah satu ikan pelagis yang memiliki peranan penting dan berpotesi cukup besar bagi produksi perikanan di kawasan Teluk Palabuhanratu dibuktikan dengan jumlah hasil tangkapan berfluktuasi dengan kecenderungan meningkat ditangkap oleh nelayan menggunakan bagan. Ikan teri hitam memiliki distribusi yang luas, baik di Samudera Pasifik maupun di Samudera Hindia dan memiliki banyak manfaat penting seperti mencegah osteoporosis dan menambah kecerdasan anak dengan gizi EPA sebesar 1,66\% dan DHA sebesar 5,87\% (Aneesh et al., 2012). Selain itu, juga memiliki peranan sebagai umpan hidup bagi penangkapan cakalang. Tingginya pemanfaatan ikan teri hitam di Teluk Palabuhanratu seharusnya diimbangi dengan upaya pengelolaan sumberdaya ikan teri hitam agar dapat dimanfaatkan secara berkelanjutan.

Potensi dan tingkat pemanfaatan sumber daya ikan yang belum diatur secara baik memberikan peluang terjadinya pemanfaatan yang berlebih. Teluk Palabuhanratu sebagai daerah penangkapan ikan terbesar di Jawa Barat, berpeluang mengalami penangkapan berlebih dengan berkembangnya alat penangkapan ikan yang dimiliki nelayan. Aktivitas penangkapan ikan yang terus meningkat dan dikhawatirkan dapat membahayakan kelestarian sumberdaya, sehingga penetapan dan penerapan kebijakan pengelolaan sumberdaya ikan berkelanjutan mutlak harus dilakukan. Pengelolaan sumberdaya perikanan yang baik yaitu dengan memanfaatkan populasi ikan tanpa harus menguras habis sumberdaya perikanan tersebut (Rahmawati et al., 2013).

Tingginya tekanan terhadap sumberdaya ikan yang semakin besar akan berdampak menimbulkan degradasi sumberdaya ikan secara besar-besaran. Penetapan dan penerapan kebijakan pengelolaan sumberdaya ikan berkelanjutan mutlak harus dilakukan. Kebijakan pengelolaan seharusnya ditunjukkan untuk mendapatkan manfaat maksimum dalam jangka panjang yang mencakup upaya menghindari tangkap lebih (over fishing) secara biologi maupun ekonomi serta upaya untuk mencegah kerusakan lingkungan perairan laut dan konflik sosial. Oleh sebab itu, diperlukan penelitian mengenai dinamika populasi dan biologi reproduksi di perairan Teluk Palabuhanratu guna menentukan alternatif pengelolaan yang lebih tepat dan berkelanjutan. Tujuan dari penelitian ini adalah untuk mengkaji dinamika populasi dan aspek biologi reproduksi ikan teri hitam di perairan Teluk Palabuhanratu.

\section{METODE PENELITIAN}

\subsection{Waktu dan Tempat Penelitian}

Penelitian dilaksanakan pada bulan Mei sampai September 2017. Lokasi pengambilan ikan contoh berasal dari Teluk Palabuhanratu yang didaratkan di Pelabuhan Perikanan Nusantara (PPN) Palabuhanratu, Kabupaten Sukabumi, Jawa Barat (Gambar 1). Analisis ikan contoh dilakukan di Lab. Biologi Perikanan, Depatemen Manajemen Sumberdaya Perairan, FPIK-IPB.

Metode yang digunakan untuk pengambilan sampel ikan adalah metode pengambilan contoh acak sederhana. Ikan contoh yang diperoleh merupakan hasil tangkapan nelayan di sekitar perairan Teluk Palabuhanratu yang didaratkan di PPN Palabuhanratu. Total ikan contoh yang tertangkap berjumlah 1838 ekor. Ikan contoh diidentifikasi terlebih dahulu berdasarkan panduan Arriaga et al. (1983). Pengambilan data panjang total ikan contoh terdiri dari beberapa variasi ukuran yang kemudian diukur dari ujung mulut sampai ujung sirip ekor menggunakan penggaris. Penimbangan bobot basah total meliputi bobot tubuh ikan serta air yang terkandung didalamnya dengan menggunakan timbangan. 

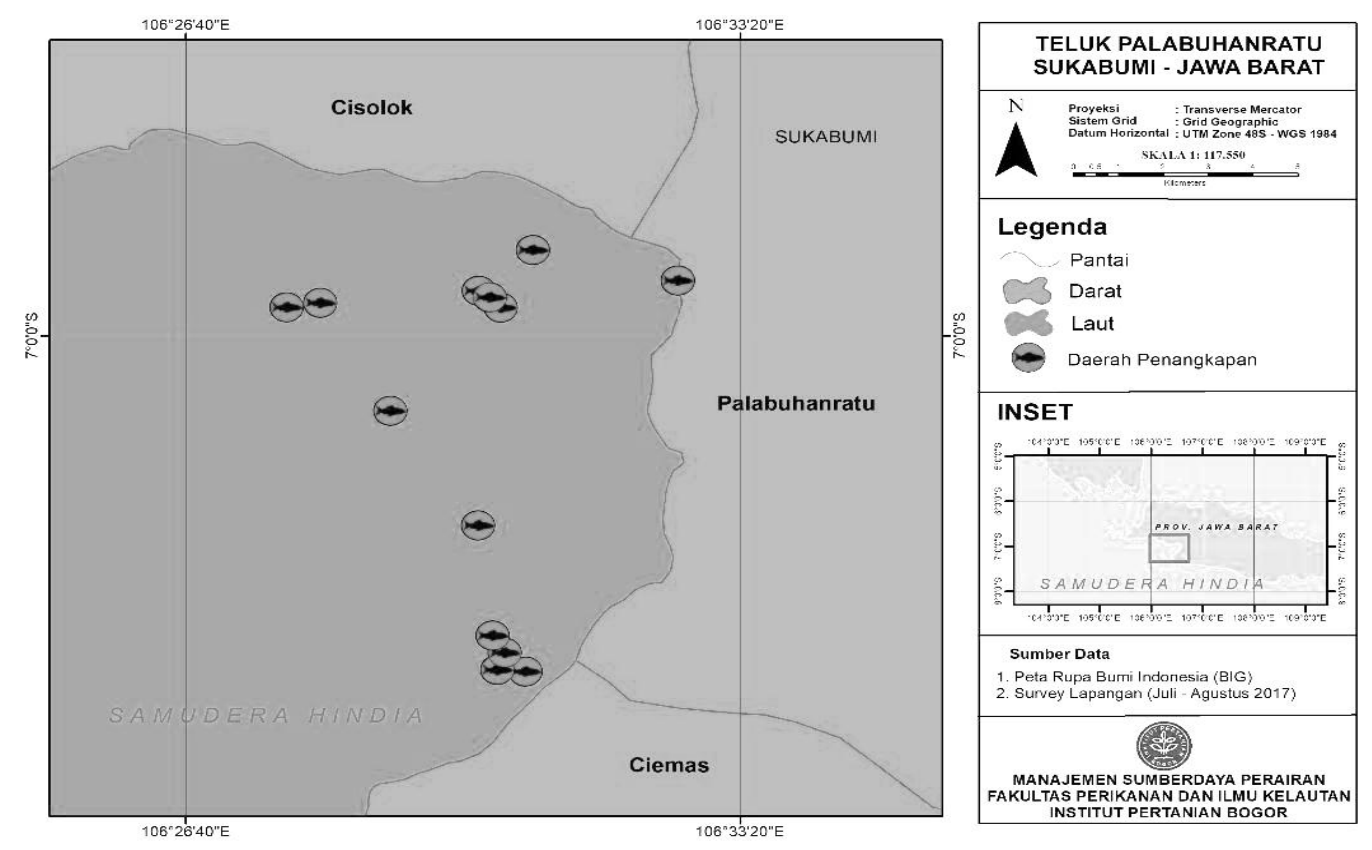

Gambar 1. Peta lokasi pengambilan contoh dan pengamatan di Teluk Palabuhanratu.

\subsection{Analisis Data}

\subsubsection{Rasio Kelamin}

Rasio kelamin dihitung dengan cara membandingkan jumlah ikan jantan dan betina. Rumus yang digunakan untuk perbandingan jantan betina adalah :

Rasio kelamin $=\frac{J}{B}$

Keterangan: J adalah jumlah ikan jantan (ekor) dan $\mathrm{B}$ adalah jumlah ikan betina (ekor).

Menentukan perbandingan jenis kelamin digunakan uji chi-square Steel and Torrie (1991) dengan rumus :

$X^{2}=\frac{\sum(o i-e i)^{2}}{e i}$

Keterangan: oi adalah frekuensi ikan jantan dan betina yang teramati, ei adalah frekuensi harapan, yaitu frekuensi ikan jantan ditambah frekuensi ikan betina dan $\mathrm{X}^{2}$ adalah chisquare hitung.

\subsubsection{Tingkat Kematangan Gonad}

Penentuan tingkat kematangan gonad (TKG) diamati secara morfologis dengan memperhatikan bentuk, warna dan ukuran gonad ikan contoh menggunakan petunjuk Arriaga et al. (1983).

\subsubsection{Sebaran Frekuensi Panjang dan Identifikasi Kelompok Umur}

Penentuan sebaran frekuensi panjang menggunakan data panjang total ikan yang tertangkap. Langkah-langkah dalam menganalisis sebaran frekuensi panjang adalah dengan menentukan jumlah kelas panjang yang dibutuhkan terlebih dahulu, menentukan interval (lebar selang kelas) dan kemudian menentukan frekuensi dari masing-masing selang kelas panjang. Identifikasi kelompok umur dilakukan dengan menganalisis frekuensi panjang melalui metode ELEFAN (Electronic Legth Frequency Analysis) (FISAT II, FAOICLARM Stock Assesment Tool). Sebaran frekuensi panjang dikelompokkan ke dalam beberapa kelompok umur yang menyebar dengan nilai rata-rata panjang dan simpangan baku pada masing-masing kelompok umur (Gayanilo et al., 1994). Menurut Boer (1996), jika $f_{i}$ adalah frekuensi ikan dalam kelas panjang ke-i $(i=1,2, \ldots, N), \mu j$ adalah rata-rata panjang kelompok umur ke-j dan $p_{j}$ 
adalah proporsi ikan dalam kelompok umur ke-j $(j=1,2, \ldots, G)$, maka fungsi objektif yang digunakan untuk menduga $\left\{\mu \mathrm{j}, \sigma_{\mathrm{j}}, \mathrm{p}_{\mathrm{j}}\right\}$ adalah fungsi kemungkinan maksimum (maximum likelihood function):

$L=\sum_{i=1}^{N} f_{i} \log \sum_{j=1}^{G} p_{j} q_{i j}$

dan

$q_{i j}=\frac{1}{\sigma_{j} \sqrt{2 \pi}} e^{-\frac{1}{2}\left(\frac{x i-\mu j}{\sigma j}\right)^{2}}$

yang merupakan fungsi kepekatan sebaran normal dengan nilai tengah $\mu \mathrm{j}$ dan simpangan baku $\sigma_{\mathrm{j}}, \mathrm{x}_{\mathrm{i}}$ adalah titik tengah kelas panjang ke-i. Fungsi objektif L ditentukan dengan cara mencari turunan pertama L masingmasing terhadap $\mu_{\mathrm{j}}, \sigma_{\mathrm{j}}$ dan $\mathrm{p}_{\mathrm{j}}$, sehingga diperoleh dugaan $\mu_{\mathrm{j}}, \sigma_{\mathrm{j}}$, dan $\mathrm{p}_{\mathrm{j}}$ yang akan digunakan untuk menduga parameter pertumbuhan

\subsubsection{Hubungan Panjang dan Bobot}

Pengukuran panjang total ikan menggunakan pengaris dengan tingkat ketelitian 1 mm. Selanjutnya dilakukan pengukuran berat individu ikan menggunakan timbangan digital dengan ketelitian 0,01 g. Kemudian hasil pengukuran dianalisis dengan program microsoft excel. Hubungan panjang berat dianalisa dengan model persamaan Hile (1936) dalam Effendie (2002):

$\mathrm{W}=\mathrm{a} L^{b}$

Keterangan: W adalah berat ikan (gram), L adalah panjang ikan $(\mathrm{cm})$ dan a,b adalah konstanta. Dari persamaan tersebut diketahui pola pertumbuhan panjang dan berat ikan tersebut. Nilai b yang diperoleh digunakan untuk menentukan pola pertumbuhan apakah polanya isometrik atau allometrik.

\section{HASIL DAN PEMBAHASAN}

\subsection{Nisbah Kelamin}

Jenis kelamin jantan dan betina ditentukan secara morfologi melalui pengamatan bentuk dan warna gonad. Nisbah kelamin atau perbandingan ikan jantan dan betina merupakan perbandingan ukuran ikan jenis kelamin jantan dan betina. Jumlah ikan yang diperoleh berbeda-beda setiap bulannya karena tergantung dari hasil tangkapan nelayan. Secara keseluruhan total ikan contoh yang diambil berjumlah 1838 ekor dengan jumlah jantan 1146 ekor dan betina 692 ekor dengan perbandingan 1,7:1 atau 63,04\% : 36,96\%. Menurut Bal and Rao (1984) perbandingan antara jumlah jantan dan jumlah betina dalam suatu populasi dengan rasio 1:1 (ikan jantan dan ikan betina masing-masing 50\%) merupakan kondisi yang ideal.

Hasil uji chi-square dengan kepercayaan 95\% menunjukkan bahwa proporsi jantan dan betina ikan teri Stolephorus commersonii dalam suatu populasi tidak seimbang pada pengambilan contoh bulan Mei, Juli Agustus dan September, sedangkan pada bulan Juni seimbang (Tabel 1) dimana jantan lebih dominan dibandingkan dengan betina. Hasil pengamatan nisbah kelamin pada penelitian ini serupa dengan penelitian Rao (1988) di Kannada yang melaporkan bahwa hasil tangkapan ikan teri jantan lebih dominan daripada betina. Keadaan tidak seimbangnya proporsi antara ikan jantan dan betina menurut Nikolsky (1963) diduga karena adanya perbedaan pola pertumbuhan, perbedaan umur, ukuran pertama kali matang gonad dan adanya penambahan jenis ikan baru pada suatu populasi ikan yang sudah ada. Tekanan penangkapan yang tinggi juga diduga dapat menyebabkan terjadinya ketidakseimbangan jumlah antara ikan jantan dan ikan betina dalam suatu populasi (Pulungan et al., 1994).

Jumlah tangkapan ikan teri tertinggi berturut-turut pada bulan Mei, Juli, September, Juni dan Agustus. Hal ini sesuai dengan Luasunaung (2011) yang menyatakan bulan-bulan musim ikan berlangsung bulan Mei sampai bulan Juli dimana puncaknya pada bulan Juni dan sedikit pada bulan November, sedangkan bukan musim ikan cenderung terjadi pada bulan Desember 
Tabel 1. Nisbah kelamin Ikan Teri hitam.

\begin{tabular}{lcccccl}
\hline \multirow{2}{*}{ Sampel } & \multicolumn{3}{c}{$\mathrm{N}$} & \multirow{2}{*}{ X hit } & \multirow{2}{*}{ X tab } & \multirow{2}{*}{ Keterangan } \\
\cline { 2 - 4 } & $\mathrm{J}$ & $\mathrm{B}$ & $\mathrm{G}$ & & & \\
\hline I (Mei 2017) & 180 & 227 & 407 & 5,430 & 3,8415 & Tidak seimbang \\
II (Juni 2017) & 167 & 153 & 320 & 0,610 & 3,8415 & Seimbang \\
III (Juli 2017) & 306 & 93 & 399 & 113,71 & 3,8415 & Tidak seimbang \\
IV (Agustus 2017) & 240 & 71 & 311 & 91,840 & 3,8415 & Tidak seimbang \\
V (September 2017) & 253 & 148 & 401 & 27,490 & 3,8415 & Tidak seimbang \\
Total & 1146 & 692 & 1838 & 39,380 & 3,8415 & Tidak seimbang \\
\hline
\end{tabular}

sampai Februari, dimana pada bulan-bulan tersebut bertiup angin barat dan bulan Agustus-September dimana pada saat itu biasanya bertiup angin timur.

\subsection{Tingkat Kematangan Gonad (TKG)}

TKG merupakan tahap perkembangan gonad sebelum dan sesudah pemijahan. Kajian tingkat kematangan gonad bertujuan untuk menentukan perbandingan antara ikan yang sudah dan belum matang gonad di perairan, ukuran ikan saat pertama kali matang gonad, waktu pemijahan, potensi pemijahan, pola pemijahan, dan lama pemijahan (Effendie, 2002). Gambar 2 menyajikan tingkat kematangan gonad ikan teri hitam berdasarkan bulan pengamatan dan selang kelas panjang ikan.

Tingkat kematangan gonad I dan II pada ikan teri hitam jantan terdapat pada selang kelas 21- $90 \mathrm{~mm}$, hal yang sama dengan ikan teri betina. TKG III jantan pada selang kelas $42-90 \mathrm{~mm}$ dan betina pada selang kelas 35-90 $\mathrm{mm}$ dan TKG IV jantan selang kelas $42-97 \mathrm{~mm}$ dan betina selang kelas 42-104 mm.
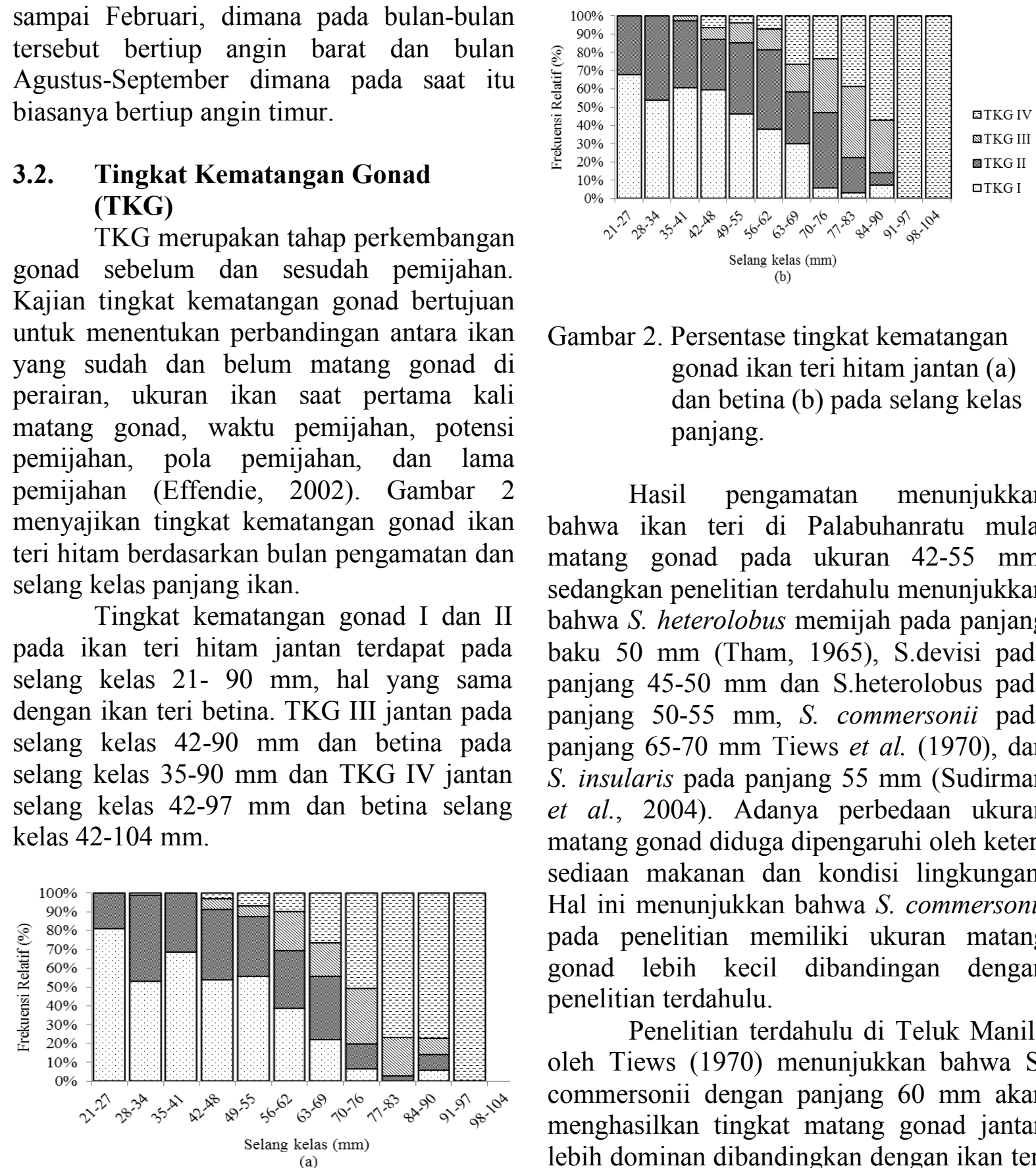

Gambar 2. Persentase tingkat kematangan gonad ikan teri hitam jantan (a) dan betina (b) pada selang kelas panjang.

Hasil pengamatan menunjukkan bahwa ikan teri di Palabuhanratu mulai matang gonad pada ukuran 42-55 mm, sedangkan penelitian terdahulu menunjukkan bahwa $S$. heterolobus memijah pada panjang baku $50 \mathrm{~mm}$ (Tham, 1965), S.devisi pada panjang 45-50 $\mathrm{mm}$ dan S.heterolobus pada panjang $50-55 \mathrm{~mm}, S$. commersonii pada panjang 65-70 $\mathrm{mm}$ Tiews et al. (1970), dan S. insularis pada panjang $55 \mathrm{~mm}$ (Sudirman et al., 2004). Adanya perbedaan ukuran matang gonad diduga dipengaruhi oleh ketersediaan makanan dan kondisi lingkungan. Hal ini menunjukkan bahwa $S$. commersonii pada penelitian memiliki ukuran matang gonad lebih kecil dibandingan dengan penelitian terdahulu.

Penelitian terdahulu di Teluk Manila oleh Tiews (1970) menunjukkan bahwa S. commersonii dengan panjang $60 \mathrm{~mm}$ akan menghasilkan tingkat matang gonad jantan lebih dominan dibandingkan dengan ikan teri 
betina, hasil yang sama dengan penelitian ini. Secara keseluruhan TKG yang paling banyak ditemukan pada penelitian ini adalah TKG I dan TKG II, dapat dikatakan masih muda dan seharusnya tidak boleh ditangkap karena apabila ukuran-ukuran tersebut ditangkap terus menerus maka proses rekruitmen tidak akan terjadi lagi karena tidak ada ikan yang memijah (Boer dan Aziz, 2007).
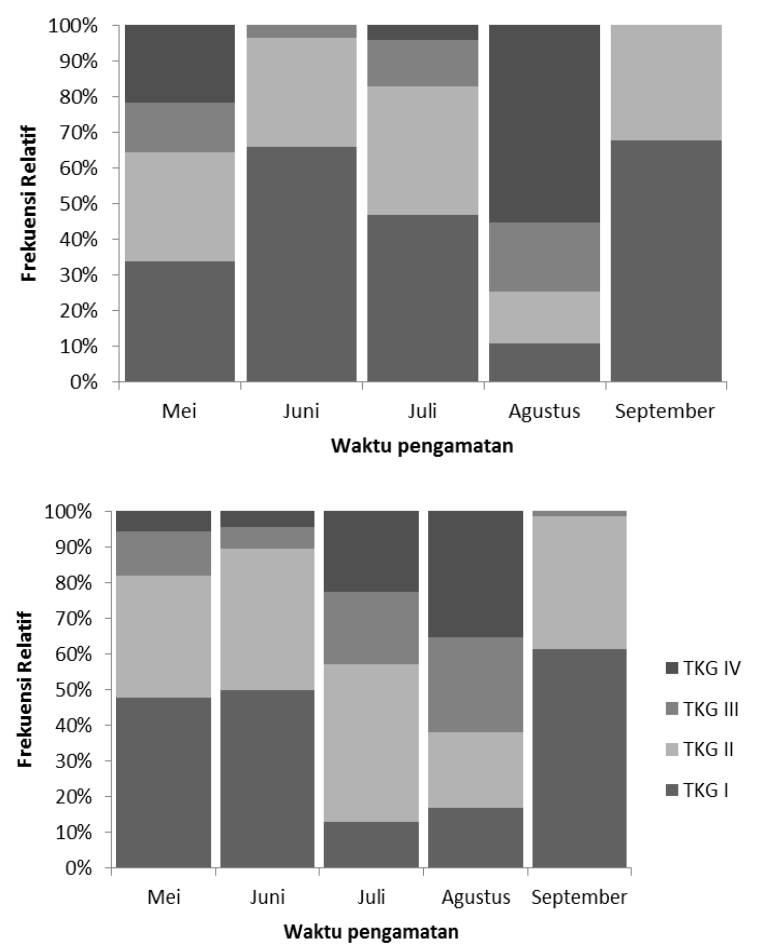

Gambar 3. Persentase tingkat kematangan gonad ikan teri hitam jantan (a) dan betina (b) pada tiap bulan pengamatan.

Pengamatan setiap bulan, ikan teri jantan dapat diketahui bahwa proporsi TKG I tertinggi pada bulan September bernilai $67,73 \%$ dan TKG IV tertinggi pada bulan Agustus bernilai 55,42\%. Ikan teri betina proporsi TKG I tertinggi pada bulan September bernilai $61,33 \%$ dan TKG IV tertinggi pada bulan Agustus bernilai $35,21 \%$. Hasil yang berbeda pada penelitian Sudirman et al. (2004) menunjukkan bahwa TKG IV atau puncak pemijahan ikan teri terjadi pada bulan Maret hingga Mei, selajutnya pada bulan Agustus kebanyakan ikan teri telah melakukan pemijahan, jika dihubungkan dengan komposisi ukuran ikan nampak bahwa pada bulan Agustus ikan teri cenderung lebih kecil, dengan kata lain dapat diduga bahwa ikan teri tersebut adalah hasil pemijahan dari bulan sebelumnya. Berdasarkan hasil TKG, dapat dikatakan bahwa musim pemijahan ikan teri hitam terjadi pada bulan Agustus dan terjadinya rekrutmen pada bulan September. Perbedaan bulan pemijahan ikan teri penelitian ini dengan ikan teri penelitian terdahulu disebabkan oleh perbedaan lokasi, selain itu faktor-faktor utama yang mampu mempengaruhi kematangan gonad ikan menurut (Effendie, 2002) antara lain suhu dan makanan, tetapi secara relatif perubahannya tidak besar dan di daerah tropik gonad dapat masak lebih cepat. Kualitas pakan yang diberikan harus mempunyai komposisi khusus yang merupakan faktor penting dalam mendukung keberhasilan proses pematangan gonad dan pemijahan.

\subsection{Sebaran Frekuensi Panjang dan Identifikasi Kelompok Umur}

Analisis sebaran frekuesi panjang dapat digunakan untuk menduga kelompok umur ikan. Hal ini disebabkan histogram frekuensi panjang ikan dapat menggambarkan beberapa kelompok umur yang masing-masing menyebar menurut sebaran normal. Jumlah ikan yang diambil berbedabeda setiap bulannya bergantung pada hasil tangkapan nelayan. Gambar 4 menyajikan sebaran frekuensi panjang total ikan teri hitam.

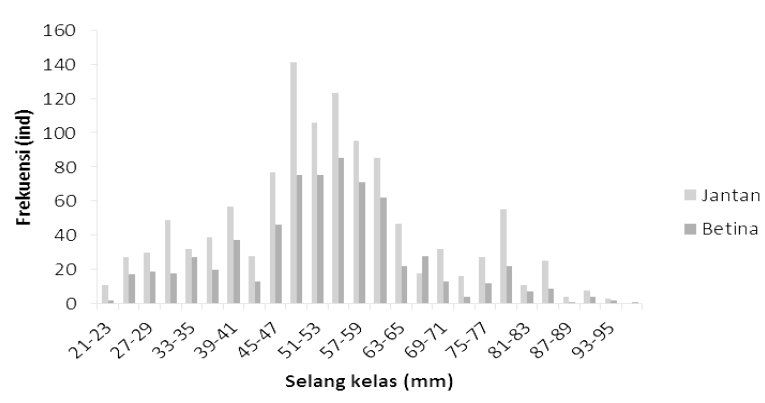

Gambar 4. Sebaran frekuensi panjang total ikan teri hitam. 
Total contoh yang diamati, panjang total ikan teri hitam menyebar berkisar dari selang kelas panjang $21 \mathrm{~mm}$ sampai dengan $98 \mathrm{~mm}$. Frekuensi panjang ikan teri hitam tertinggi terdapat pada selang kelas $51 \mathrm{~mm}$ sampai $56 \mathrm{~mm}$. Persebaran total panjang ikan teri di Palabuhanratu tidak berbeda jauh dengan penelitian Dewanti et al. (2014) di Kabupaten Pemalang dengan sebaran frekuensi 37-81 mm. Hasil penelitian Kusuma et al. (2014) di Perairan Morodemak memiliki ukuran panjang total berkisar antara 7-9 $\mathrm{cm}$ dengan ukuran yang mendominasi 8 $\mathrm{cm}$. Sebaran frekuensi dapat memberikan informasi penting dalam mengkaji suatu popuasi dan stok.

Analisis kelompok umur dilakukan berdasarkan sebaran frekuensi panjang total ikan yang diamati pada setiap pengambilan contoh. Kelompok umur dapat diketahui dengan mengelompokkan ikan dalam kelaskelas panjang dan menggunakan modus panjang kelas tersebut untuk mewakili panjang kelompok umur. Hasil identifikasi kelompok umur dapat digunakan untuk menghitung pertumbuhan atau laju pertumbuhan. Gambar 5 menyajikan pergeseran kelompok umur ikan teri hitam pada bulan Mei sampai September 2017 dengan menggunakan metode ELEFAN yang terdapat pada program FISAT II.

Tabel 2 menjelaskan bahwa setiap jenis ikan memiliki kelompok umur yang bervariasi. Ikan teri memiliki satu sampai dua kelompok umur (modus panjang) dan didominasi oleh satu kelompok umur serta modus panjang ikan mengalami peningkatan pada setiap pengambilan contoh (sampling). Sebagai contoh, pada sampling pertama mempunyai modus panjang adalah 58,91 $\mathrm{mm}$, sampling kedua adalah $51,37 \mathrm{~mm}$, pada sampling ketiga adalah $56,50 \mathrm{~mm}$ dan pada sampling keempat adalah 43,46 $\mathrm{mm}$ dan 78,47 .

Peningkatan nilai modus panjang ikan menunjukkan terjadinya pertumbuhan individu pada populasi ikan tersebut. Pada sampling kelima muncul nilai modus panjang baru, yaitu 35,20 mm. Hal ini menunjukkan terjadinya rekruitmen atau penambahan baru populasi ikan teri ke dalam stok. Namun, terdapat pula modus panjang yang hampir sama pada periode pengambilan contoh yang berbeda.

Hasil penelitian Yuanda et al. (2015) analisis kelompok ukuran ikan teri pekto di Belawan menunjukkan terdapat tiga kelompok umur dan hal ini menunjukkan terdapat tiga kohort atau generasi yang hidup bersama dalam satu waktu di lingkungan perairan yang sama. Menurut Suwarso dan Hariati (2002) yang menyatakan bahwa kelompok ukuran (kohort) yaitu sekelompok individu ikan dari jenis yang sama yang berasal dari pemijahan yang sama.

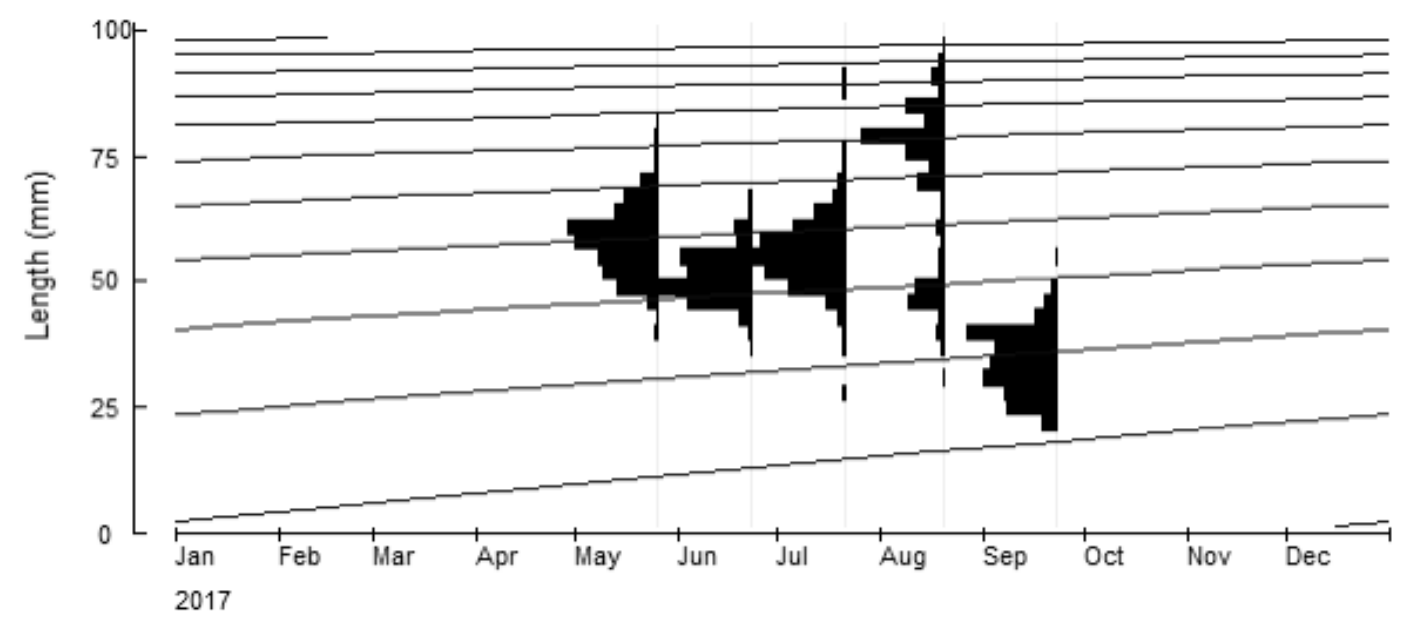

Gambar 5. Pergeseran modus frekuensi panjang ikan teri hitam. 
Tabel 2. Kelompok umur ikan teri.

\begin{tabular}{ccccc}
\hline Jenis Ikan & Sampling & $\begin{array}{c}\text { Kelompok } \\
\text { umur }\end{array}$ & Panjang, L (mm) & Bobot, W (gram) \\
\hline Ikan Teri & 1 & 1 & 58,91 & 1,1267 \\
& 2 & 1 & 51,37 & 0,7240 \\
& 3 & 1 & 56,50 & 1,1776 \\
& 4 & 1 & 43,46 & 0,5080 \\
& 5 & 1 & 78,47 & 3,8147 \\
& & 1 & 35,20 & 0,3378 \\
\hline
\end{tabular}

Hasil penelitian menunjukkan bahwa terjadinya pergeseran modus ke arah kanan pada bulan Mei hingga bulan September. Pergeseran kelompok umur dari suatu kelompok panjang ke kelompok panjang selanjutnya menandakan terjadinya pertumbuhan dan rekrutmen ikan. Perbedaan struktur data panjang dan komposisi kelompok umur pada ikan contoh disebabkan oleh perbedaan karakteristik masing-masing jenis atau spesies ikan. Selain itu, disebabkan pula oleh pertumbuhan dan pola rekruitmen serta ukuran ikan yang tertangkap oleh nelayan di setiap pengambilan contoh dan lokasi penangkapannya. Setiap perairan memiliki karakteristik yang berbeda-beda, baik faktor lingkungan, makanan, dan lain sebagainya.

\subsection{Hubungan Panjang Bobot}

Analisis mengenai hubungan panjang bobot dimanfaatkan untuk mengetahui pola pertumbuhan suatu organisme dan kelompok umur. Hasil perhitungan hubungan panjang dan bobot pada gambar 6 memberikan persamaan $\mathrm{W}=0,0000587 \mathrm{~L}^{2.4391}$ pada ikan teri jantan dengan nilai koefisien determinasi $\left(\mathrm{R}^{2}\right)$ sebesar 0,7796 dan $\mathrm{W}=0,0000891 \mathrm{~L}^{2.3264}$ untuk teri betina denga koefisien determinasi $\left(\mathrm{R}^{2}\right)$ 0,7326. Model ini menunjukkan bahwa pertumbuhan ikan teri hitam jantan lebih cepat dibandingkan dengan betina karena memiliki koefisien pertumbuhan yang lebih besar. Berdasarkan uji lanjut diketahui bahwa $\mathrm{t}_{\text {tabel }}<\mathrm{t}_{\text {hitung }}$ untuk ikan teri jantan dan betina yang berarti tolak $\mathrm{H}_{0}$ dimana $\mathrm{b} \neq 3$ sehingga memiliki pertumbuhan alometrik. Fungsi dari hubungan panjang bobot diketahui $b<3$ yang berarti pertumbuhan alometrik negatif atau pertumbuhan panjang lebih dominan dibandingkan bobot.

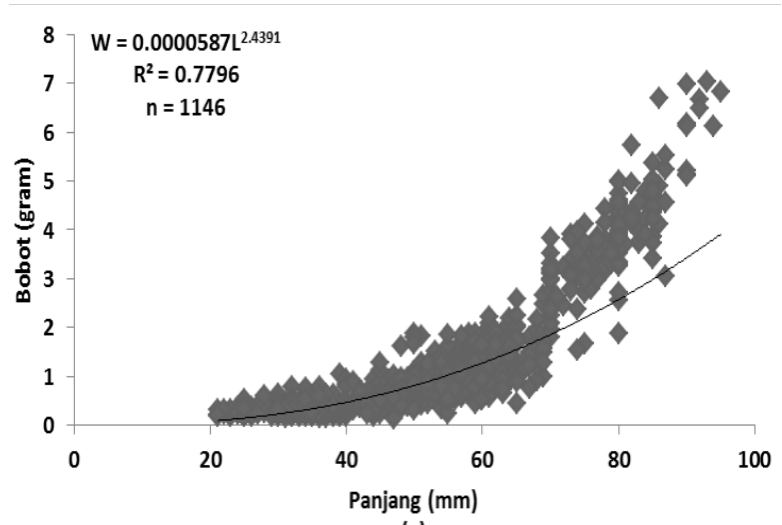

(a)

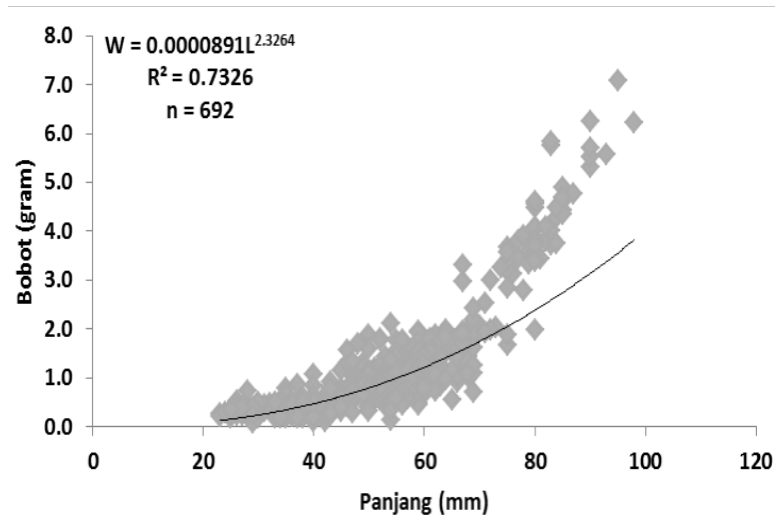

(b)

Gambar 6. Hubungan panjang bobot ikan teri hitam.

Penelitian Dewanti et al. (2014) menyatakan pola pertumbuhan Stolephorus devisi di Kabupaten Pemalang memiliki pola pertumbuhan alometrik positif dengan nilai a 
sebesar 0,0000047 dan nilai b sebesar 3,125. Rao (1988) menyatakan bahwa Stolephorus devisi memiliki nilai $\mathrm{b}=3,013$ dan penelitian (Yuanda et al., 2015) di Belawan menghasilkan ppola pertumbuhan alometrik negatif dengan nilai $a=0,007$ dan nilai $b=$ 2,975. Hasil yang serupa pada penelitian Nair et al. (2015) di Pantai Kerala menunjukkan nilai $\mathrm{a}=0,00756$ dan $\mathrm{b}=2,99$ untuk stolephorus commersonii betina, sedangkan ikan jantan memberikan nilai $\mathrm{a}=0,0070$ dan $\mathrm{b}=3,16$. Perbedaan nilai koefisien $\mathrm{b}$ diduga karena ketersediaan makanan, perbedaan jenis kelamin, kematangan gonad, lokasi dan kondisi kualitas perairan pada saat pengambilan contoh.

Perbedaan pola pertumbuhan dipengaruhi oleh beberapa faktor internal dan eksternal. Faktor internal yang mempengaruhi pola pertumbuhan adalah genetik dan perkembanan gonad sedangkan faktor eksternal adalah lingkungan dan ketersediaan makanan (Effendie, 2002). Pola pertumbuhan juga dipengaruhi oleh tingkah laku ikan yang bergerak aktif dan melakukan ruaya (Utami et al., 2014).

\section{KESIMPULAN}

Ikan teri hitam yang tertangkap sebagian besar adalah ikan muda atau ikanikan yang belum matang gonad. Dari contoh ikan yang tertangkap, kelestarian sumberdaya ikan teri hitam di Teluk Palabuhanratu dapat ditempuh dengan melakukan penangkapan yang difokuskan kepada ikan-ikan yang berukuran lebih besar agar memberikan kesempatan bagi ikan-ikan tersebut untuk menyiapkan generasi penerusnya.

\section{UCAPAN T ERIMA KASIH}

Terima kasih kepada Direktur Jenderal Pendidikan Tinggi, Kementrian Pendidikan dan Kebudayaan atas biaya penelitian melalui Biaya Operasional Perguruan Tinggi Negeri (BOPTN), Anggaran Pendapatan Belanja Negara (APBN),
DIPA IPB Tahun Ajaran 2017, Nomor 011/SP2H/LT/DRPM/VIII/2017, Penelitian Dasar untuk Bagian, Penelitian Unggulan Perguruan Tinggi, Lembaga Penelitan dan Pengabdian kepada Masyarakat, IPB dengan judul "Dinamika Populasi dan Biologi Reproduksi Ikan Ekologis dan Ekonomis Penting di Teluk Palabuhanratu, Sukabumi" yang dilaksanakan oleh Prof. Dr. Ir. Mennofatria Boer, DEA (ketua peneliti) dan Dr. Ir. Rahmat Kurnia, M.Si. (anggota peneliti).

\section{DAFTAR PUSTAKA}

Aneesh, P.A., J. Varkey, R. Anandan, S. Mathew, K.K. Ash, P.T. Lakshmanan, T.V. Sankar, and B.P. Mohanty. 2012. Omega- 3 polyunsaturated fatty acid profile of four indian food fishes of Arabian Sea. Nutritional Medicine Health \& Wellness, 295-300.

Ardelia, V., Y. Vitner, dan M. Boer. 2016. Biologi reproduksi ikan tongkol euthynnus affinis di Perairan Selat Sunda. J. Ilmu dan Teknologi Kelautan Tropis, 8(2): 689-700. http://dx.doi.org/10.29244/jitkt.v8i2.1 5835.

Arriaga, L.S., Coello, and L. Mariduena. 1983. Escala de madurez sexual para los principales peces pelagicos en aguas ecuatorianas. Rev. Vienc Mar Limnol., 2(1):69-78.

Bal, D.V. and K.V. Rao. 1984. Marine fisheries. Tata Mc Graw-Hill Publishing Company Limited. New Delhi. $470 \mathrm{p}$.

Boer, M. 1996. Pendugaan koefisien pertumbuhan $(\mathrm{L} \infty, \mathrm{K}, \mathrm{t} 0)$ berdasarkan data frekuensi panjang. J. Ilmu-ilmu Perairan dan Perikanan Indonesia, 4(1):75 - 84.

Boer, M. dan K.A. Aziz. 2007. Gejala tangkap lebih perikanan pelagis kecil di Perairan Selat Sunda. J. Ilmu-ilmu Perairan dan Perikanan Indonesia, 14(2): 167-172. 
Dewanti, R.O.N., A. Ghofar, dan S.W. Saputra. 2014. Beberapa aspek biologi ikan teri (Stolephorus devisi) yang tertangkap payang di Perairan Kabupaten Pemalang. Diponegoro J. of Maquares, 3(4):102-111.

Effendie, M.I. 2002. Biologi perikanan. Yayasan Pustaka Nusatama. Yogyakarta. $161 \mathrm{hlm}$.

Gayanilo, F.C. Jr, P. Sparre, and D. Pauly. 1994. The FAO-ICLARM stock assessment tools (FISAT) user's guide. FAO Computerized Information Series (Fisheries) No. 8 Rome, FAO. 124 p.

Kusuma, C.P.M., H. Boesono, dan A.D.P Fitri. 2014. Analisis hasil tangkapan ikan teri (Stolephorus sp.) dengan alat tangkap bagan perahu berdasarkan perbedaan kedalaman di Perairan Morodemak. J. of Fisheries Resources Utilization Management and Technology, 3(4):102-110.

Luasunaung, A. 2011. Analisis musim penangkapan ikan teri (Stolephorus sp.) di Teluk Dodinga, Kabupaten Halmahera Barat. J. Perikanan dan Kelautan Tropis, 7(1):6-11.

Nair, P.G., S. Joseph, and V.N. Pillai. 2015. Length-weinght relationship and relative condition factor of Stolephorus commersonii (Lacepede, 1803 ) exploited along Kerala coast. $J$. Marine Biological Association of India. 57(2):27-31. Doi: 10.6024/ jmbai.2015.57.2.01856-04.

Nikolsky, G.V. 1963. The ecology of fishes. Academic Press. London. 325 p.

Pulungan, C.P., Nuraini, dan Efriyeldi. 1994. Aspek biologi reproduksi ikan bujuk (Ophiocephalus lucius C. V.) dari perairan sekitar Teratak Buluh, Riau. Pusat Penelitian Universitas Riau, Pekanbaru. $54 \mathrm{hlm}$.

Rahmawati, M., A.D.P. Fitri, dan D. Wijayanto. 2013. Analisis hasil tangkapan per upaya penangkapan dan pola musim penangkapan ikan teri (Stolephorus spp.) di Perairan Pemalang. J. of Fisheries Resources Utilization Management and Techno., 2(3):213-222.

Rao, G.S. 1988. BiologY of Stolephorus devisi (Whitley) from Mangalore Area 4, Dakshina Kannada. J. of the Marine Biological Association of India, 30(1\&2): 28-36.

Rao, G.S. 1988. Some aspects of biology of Stolephorus bataviensis Hardenberg, from mangalore area, Dakshina Kannada. J. of the Marine Biological Association of India, 30(1\&2): 107113.

Steel, R.G.D. dan J.H. Torrie. 1991. Prinsip dan Prosedur Statistika. Diterjemahkan oleh Bambang Sumantri. PT. Gramedia Pustaka Utama. Jakarta. $747 \mathrm{hlm}$.

Sudirman, M. Kurnia, M.S. Baskoro, A. Purbayanto. 2004. Distribusi frekuensi panjang dan tingkat kematangan gonad (TKG) ikan teri (Stolephorus insularis) yang tertangkap pada bagan rambo, kaitannya dengan penangkapan ikan bertanggung jawab. J. Torani, 2(14): 96103.

Suwarso dan T. Hariati. 2002. Identifikasi kohort dan dugaan laju pertumbuhan ikan pelagis kecil di Laut Jawa. J. Penelitian Perikanan Indonesia. 8(4):7-14.

Tham, A.K. 1965. Notes on the biology of the anchovy, Stolephorus pseudoheterolobus Handerberg. Bull. Nat. Mus., 33(4):23-26.

Tiews, K. I.A. Ronquillo, and L.M.Santos, 1970. On the biology of anchovies (Stolephorus Lacepede) in Philippines waters. Proc. Indo. Indo. Facific. Fish.Counc, 12(2):1-25.

Utami, M.N.F., S. Redjeki, dan E. Supriyantini. 2014. Komposisi isi lambung ikan kembung lelaki (Rastrelliger kanagurta) di Rembang. $J$. of Marine Research, 2(3):99-106. 
Yuanda, D., M.B. Mulya, dan A. Muhtadi. Diterima :20 April 2018 2015. Pertumbuhan dan laju eks- Direview : $07 \mathrm{Mei} 2018$ ploitasi ikan teri pekto (Stolephorus Disetujui : 23 Juli 2018 waitei) di Perairan Belawan Kota Medan Sumatera utara. $J$. Aquacoastmarine. 15(1):120-130. 
